\title{
On the historical origins of the contemporary notion of incommensurability: Paul Feyerabend's assault on conceptual conservativism
}

\author{
Eric Oberheim \\ Department of Philosophy, Humboldt University of Berlin, Unter den Linden 6, 10099 Berlin, Germany
}

Received 10 August 2004; received in revised form 21 October 2004

\begin{abstract}
This paper investigates the historical origins of the notion of incommensurability in contemporary philosophy of science. The aim is not to establish claims of priority, but to enhance our understanding of the notion by illuminating the various issues that contributed to its development. Kuhn developed his notion of incommensurability primarily under the influence of Fleck, Polanyi, and Köhler. Feyerabend, who had developed his notion more than a decade earlier, drew directly from Duhem, who had developed a notion of incommensurability in 1906. The idea is that in the course of scientific advance, when fundamental theories change, meanings change, which can result in a new conception of the nature of reality. Feyerabend repeatedly used this notion of incommensurability to attack various forms of conceptual conservativism. These include the logical positivists' foundational use of protocol statements, Heisenberg's methodological principle that established results must be presupposed by all further research, attempts to separate philosophical accounts of ontology from physics, Bohr's principle of complementarity, and logical empiricist accounts of reduction and explanation. Focusing on the function of the notion of incommensurability common to Feyerabend's various critiques explicates Feyerabend's early philosophy as a series of challenges to forms of conceptual conservativism.
\end{abstract}

(c) 2005 Elsevier Ltd. All rights reserved.

E-mail address: oberheime@philosophie.hu-berlin.de (E. Oberheim). 
Keywords: Incommensurability; Paul Feyerabend; Thomas Kuhn; Pierre Duhem; Wolfgang Köhler; Ludwik Fleck.

\section{Introduction}

The notion of incommensurability has undoubtedly been one of the major themes in the history and philosophy of science in the last half-century. ${ }^{1}$ As Thomas Kuhn and Paul Feyerabend are commonly credited with introducing this provocative idea in independent publications in 1962, it may come as a surprise to learn that Feyerabend had developed his notion of incommensurability more than a decade prior to the publication of Kuhn's The structure of scientific revolutions. However, the idea is even older than that.

This paper begins with a brief examination of the historical origins of Kuhn's notion of incommensurability. The goal is not to determine the relation between Kuhn's notion of incommensurability and that of his predecessors. (That would be at least an essay in itself.) Rather, the point is merely to emphasize the significant similarities and differences between Kuhn and Feyerabend's routes to their notions. The main bulk of the paper chronicles the less well known story of Feyerabend's development of his notion of incommensurability. The aim is not to establish claims of priority, but to enhance our understanding of the notion. By examining its historical origins, and by exploring the various issues that contributed to Feyerabend's development of it, the paper attempts to contribute to a clearer understanding of the idea and its philosophical significance. As we shall see, the main issues that shaped Feyerabend's development of the notion of incommensurability prior to 1962 include a contextual theory of meaning and Gestalt psychology. He refined the idea in attacks on the logical positivists' foundational use of protocol statements, Heisenberg's methodological principle that established results must be presupposed by all further research, attempts to separate philosophical accounts of ontology from physics, Bohr's principle of complementarity, and logical empiricist accounts of reduction and explanation. Focusing on the function of the notion of incommensurability common to Feyerabend's various critiques explicates Feyerabend's early philosophy as a series of challenges to forms of conceptual conservativism based on the idea that in the course of scientific advance, when fundamental theories change, meanings change, which can result in a new conception of the nature of reality. ${ }^{2}$

\section{The origins of Kuhn's notion of incommensurability (1962)}

In independent 1962 publications, both Feyerabend and Kuhn used the term 'incommensurable' to describe certain aspects of dramatic theoretical transitions in

\footnotetext{
${ }^{1}$ See the incommensurability bibliography in Hoyningen-Huene \& Sankey (2001).

${ }^{2}$ For a more comprehensive account of Feyerabend's early philosophy, see Oberheim (forthcoming).
} 
the course of scientific advance. ${ }^{3}$ As legend has it, the modern use of the term 'incommensurable' is the product of conversations between Kuhn and Feyerabend that took place in Berkeley, California, on Telegraph Avenue around 1960 (Hacking, 1983, p. 67). However, although Feyerabend had read and extensively commented on a draft of Kuhn (1970a [1962]) in 1960/1961, ${ }^{4}$ Feyerabend had independently developed his notion of incommensurability, and had even independently been using the term 'incommensurable'. ${ }^{5}$

Kuhn initially used the term to capture methodological, observational, and conceptual disparities between successive scientific paradigms that he had encountered in his historical investigations of the natural sciences (Kuhn, 1970a [1962], pp. 148-150). ${ }^{6}$ Later, he used the idea to argue that there is translation failure due to differences in the taxonomic structures of successive scientific theories. ${ }^{7}$ Kuhn's developing notion of incommensurability has received much attention, and it continues to provoke plenty of discussion. ${ }^{8}$

According to Kuhn, he arrived at the notion of incommensurability sometime in the mid to late 1940s as a graduate student, while attempting to understand what at first appeared to be nonsensical passages that he encountered in Aristotle's physics. 9 However, the notion of incommensurability is conspicuously lacking from Kuhn (1957), and Kuhn has been accused (by various sources) of having borrowed the idea (from various sources) without having given them their due credit.

For example, Agassi recently claimed that Kuhn 'borrowed' the idea from Duhem, and that 'Kuhn ignored his debt to Duhem' (Agassi, 2002, p. 409). In addition, according to Agassi, Kuhn denied (in a personal communication) ever having read Duhem. Agassi argues that this is highly implausible, as all members of Conant's circle, such as Kuhn, were familiar with Duhem's work. Thus, Agassi is 'puzzled' by Kuhn's claim that incommensurability was the central innovation of his famous 1962 book, as 'the word [incommensurability] denotes an important idea that Duhem explained in some detail. It is that we do not forget old theories even after they are dated' (ibid., p. 410; italics inserted). This idea, however, does not at all capture

\footnotetext{
3 There have always been some significant differences in their conceptions of incommensurability. See Feyerabend (1977) and (1978), pp. 66-67; Hoyningen-Huene (2000a, 2001, forthcoming).

4 See Feyerabend (1995 [1960/1961]).

5 Feyerabend claimed that his notion of incommensurability pre-dated the 1962 introduction of the term by about a decade. See Feyerabend (1988), pp. 228 ff. and (1993), p. 211. See also Feyerabend (1970b), p. 219; Kuhn (1983), pp. 669, 684 n. 2; (2000), pp. 297-298. For discussions, see Hoyningen-Huene (1993), p. 207; Preston (1997a), pp. 102-104, 216-217; Hoyningen-Huene (forthcoming).

${ }^{6}$ See Hoyningen-Huene (1993), p. 206 and Sankey (1993).

7 According to Sankey, Kuhn's notion of incommensurability underwent a major transformation to the point that his later notion has little in common with his original account. See Sankey (1993, 1998). Feyerabend can be interpreted as having anticipating Kuhn's 1990s notion of taxonomic incommensurability, with his 1965 claim that two theories are incommensurable if a new theory entails that all the concepts of the preceding theory have zero extension or if it introduces rules ... which change the system of classes itself' (Feyerabend, 1965a, p. 268). See also Carrier (2001), p. 88.

${ }^{8}$ For example, see Hoyningen-Huene (1993); Sankey (1993); Bird (2003).

9 Kuhn (1991), p. 4. For more on Kuhn's account of his discovery of incommensurability, see Kuhn (1977), pp. xi-xiii; (1981), pp. 3-6; (1989), pp. 49-50; (1991), p. 4; (1999), p. 33.
} 
Kuhn's notion of incommensurability. Moreover, Agassi offers no evidence suggesting either that Duhem had actually developed a notion of incommensurability, or that Kuhn had borrowed the idea from Duhem.

Struan Jacobs has also recently rejected Agassi's claim about Kuhn's unpaid debt to Duhem. However, Jacobs proceeds to accuse both Kuhn and Feyerabend of having appropriated the idea of incommensurability from Michael Polanyi, without having given Polanyi his due credit. ${ }^{10}$ By 1958, Polanyi had indeed developed a notion of incommensurability that was similar to Kuhn's in some significant respects, ${ }^{11}$ and Jacobs presents some strong evidence in support of Kuhn's unpaid debt to Polanyi. ${ }^{12}$ However, Jacobs's account of Polanyi as the source of Kuhn's notion of incommensurability is incomplete, as it does not temper Kuhn's debt to Polanyi in light of Kuhn's debt to Ludwik Fleck.

In the foreword of Kuhn (1970a [1962]), Kuhn acknowledged Fleck's work as anticipating many of his ideas, and he candidly admitted that although readers will find few references to Fleck, he is indebted to Fleck 'in more ways than [he] can now reconstruct or evaluate' (ibid., p. vii). Fleck's concept of a 'thought-style' clearly anticipates several senses of Kuhn's central notion of a 'paradigm', ${ }^{13}$ and Fleck had presented a phasemodel of scientific development covering pre-normal and normal science. He even illustrated the idea with some of the same examples Kuhn later adopted. ${ }^{14}$

Kuhn's debt to Fleck also directly concerns the notion of incommensurability. Fleck's book, Genesis and development of a scientific fact, discusses conceptual change at length. ${ }^{15}$ It emphasizes that terms acquire their meanings from their theoretical context, and that those meanings change through theoretical transitions. ${ }^{16}$ Kuhn even used some of the same examples as Fleck did to explain meaning change (such as the concepts of chemical 'elements' and 'compounds'). ${ }^{17}$ Moreover, they both emphasized the theory-ladeness of observation, and they both drew explicitly from Gestalt psychology, stressing that theory can determine the perception of meaning. They both even acknowledged Wolfgang Köhler in this regard. ${ }^{18}$

\footnotetext{
${ }_{10}$ See Jacobs (2002), p. 106 and (2003), pp. 58, 69, 70.

11 For a comparison, see Jacobs (2002, 2003).

12 Polanyi had also used the term 'incommensurable' in 1951 and 1958, but in contexts clearly different from those of Kuhn and Feyerabend. See Polanyi (1958), p. 174 and (1951), p. 100. For a discussion of these and other uses of the term outside the context of philosophy of science, see Jacobs (2002), p. 111 and (2003), pp. 59-60.

13 There are also many significant differences between Fleck's thought-styles and Kuhn's paradigms. For a discussion, see Babich (2003).

${ }^{14}$ See Fleck (1979 [1935]), pp. 83 ff.

15 See ibid., pp. 9, 10, 19, 20-21, 25-28, 53, 36, 38-41, 53-54, 62, 64, 92-95, 98, 110, 122-123, 128.

16 See ibid., pp. 25, 39, 40, and especially pp. 53-54.

17 See ibid., pp. 122-123, 128 and compare Kuhn (1970a [1962]), pp. 130-134.

18 See Fleck (1979 [1935]), pp. 16, 44, 90-93, 120, 133, 142; (1986b [1935]), pp. 76-78; (1986c [1936]), pp. 84-85, and compare Kuhn (1970a [1962]), e.g. p. 204. Kuhn acknowledged his debt specifically to Gestalt psychology (ibid., p. vi), and to Köhler (1979, p. ix). For an excellent discussion of Kuhn's use, and subsequent retraction, of the Gestalt metaphor to characterize theoretical advance, see Hoyningen-Huene (1993), pp. 38-41, 204-205. For an introduction into Gestalt psychology including some aspects of its philosophical significance, see Köhler (1947).
} 
In 1927, Fleck had used the term 'incommensurable' to describe the in principle differences between 'medical thinking', which attempts to understand irregular, temporally dynamic phenomena such as an illness, and 'scientific thinking', which attempts to understand uniform phenomena such as atomism in chemistry and energetics in physics (Fleck, 1986a [1927], pp. 44-45). And in 1935, Fleck had used the term 'incommensurable' to describe conceptual replacements in theoretical transitions in science: 'The old concept of disease thus becomes quite incommensurable with the new concepts and is not replaced by a completely adequate substitute' (Fleck, 1979 [1935], p. 62). ${ }^{19}$

Kuhn, who was instrumental in having Fleck (1935) translated and then published in English, emphasized that his 'revelation' (his discovery of incommensurability) had occurred several years before he had read Fleck (in 1949 or 1950) (Kuhn, 1979, p. vii). In fact, it was this revelation that had led him to Fleck in the first place (ibid). Kuhn also explicitly emphasized that, at that time, he was 'much engaged in exploring Köhler, Koffka, and other gestalt psychologists' (ibid., p. ix). As we shall see, Gestalt psychology's stress on the theory-ladeness of observation, and on our ability to perceive certain meanings only after we are in the possession of a particular theory is the main similarity in Kuhn and Feyerabend's developments of their notions of incommensurability.

Thus, Fleck had developed a notion of incommensurability that anticipates Kuhn's, and Kuhn explicitly acknowledged his debt to Fleck. While this does not exclude Jacobs's claims about Kuhn's unpaid debt to Polanyi, Fleck was arguably the main influence on Kuhn's development of his notion of incommensurability.

As we have seen, Jacobs claims that Polanyi was also the source of Feyerabend's notion of incommensurability, and he claims that 'there is no express textual evidence' suggesting that Duhem contributed to Feyerabend's understanding of incommensurability (Jacobs, 2003, p. 60). As we shall see, both of these claims are incorrect.

\section{Incommensurability and logical empiricism: Feyerabend's attack on the conceptual conservativism implicit in formal accounts of reduction and explanation (1962)}

Feyerabend's use and development of the notion of incommensurability has received less attention than has Kuhn's. John Preston has suggested that Feyerabend developed his theory of meaning, and subsequently his notion of incommensurability, based on his misreading of Wittgenstein (Preston, 1997a, pp. 23 ff.). However, as we shall see, this too is incorrect.

In his landmark 1962 paper 'Explanation, reduction and empiricism', Feyerabend initially introduced the term 'incommensurable' as part of a criticism of the conceptual conservativism that he found in Nagel's theory of reduction and the

\footnotetext{
${ }^{19}$ This sentence and the term 'inkommensurabel' appear in Fleck (1979 [1935]) on p. 82.
} 
Hempel-Oppenheim theory of explanation. ${ }^{20} \mathrm{He}$ argued that formal accounts of reduction and explanation are impossible for general theories for two reasons.

The first reason that formal accounts fail is because some pairs of successive scientific theories that are supposed to be formally reducible are actually logically inconsistent. (This is not a case of incommensurability, which is the second 'qualitative reason' for the failure of formal accounts. $)^{21}$ Feyerabend illustrated the point by challenging one of Nagel's favourite examples of a purported formal reduction: the reduction of Galilean to Newtonian physics. A basic assumption of Galilean physics is that the acceleration of a free-falling body is constant over any finite interval. According to Newtonian physics, the acceleration of a free-falling body is never constant. It always increases during its fall, due to the fact that the body approaches the centre of attraction. If the height of the fall is negligible compared to the radius of the earth, then the effect will also be negligible. However, if the height is significant as compared to the radius of the earth, then this effect will be considerable, and Galileo's theory will produce false results. Galilean physics can indeed be logically derived from Newton's theory, but only by introducing a false assumption (that the height of the fall divided by the radius of the earth is zero). According to Feyerabend, '[i]t is therefore impossible, for quantitative reasons, to establish a deductive relationship between these two theories' (1962, p. 47; italics in original).

Let us briefly focus on this argument and its historical origins. This is instructive for two reasons. First, it will help to clarify a misunderstanding: in his analysis of incommensurability, Preston conflates Feyerabend's first quantitative reason for the failure of formal accounts (logical inconsistency) with his second qualitative reason (incommensurability), and subsequently unjustly criticizes Feyerabend for being inconsistent about inconsistency and incommensurability (Preston, 1997a, pp. 105106). The mistaken view that between the 1960s and the 1970s Feyerabend changed his notion of incommensurability from implying logical contradiction to denying the possibility of logical contradiction is the result of conflating Feyerabend's two distinct reasons for the failure of formal accounts (quantitative and qualitative). Second, the historical origins of this argument illuminate the historical origins of its compliment, the second qualitative reason for the failure of formal accounts (i.e. incommensurability).

The point that some pairs of successive scientific theories are logically inconsistent had been made by Popper (1957). Moreover, Popper had used exactly the same example as Feyerabend to make the point that, 'logic, whether inductive or deductive, cannot possibly make the step from [Galileo's theory] to Newton's' (1972

\footnotetext{
${ }^{20}$ I will work from the original 1962 version. It differs significantly from the 1981 reprint. For example, Feyerabend removed many acknowledgements to Popper, and he removed a lengthy passage in which he had explicitly emphasized his support for a normative approach to the philosophy of science over the descriptive approach of the historical school.

${ }^{21}$ Feyerabend clearly distinguished 'quantitative reasons' for the failure of formal accounts (logical inconsistency), discussed in Sections 3 and 4, from the 'qualitative reason' for the failure of formal accounts (i.e. incommensurability), discussed in Sections 5 through 7. (Sections 1 and 2 introduce formal accounts, and the last Section 8 , is the conclusion).
} 
[1957], pp. 199-202). Popper also illustrated this point with another example, arguing that 'Kepler's third law contradicts Newton's theory in precisely the same way as Galileo's' (1972 [1957], p. 200). In order to establish deductive relations between Kepler's third law (the planet's orbits are perfect ovals) and Newton's theory, one has to make either one of two false assumptions: either that the mass of the sun is equal to the mass of the planet, or that the mass of the planet is zero. Otherwise, the two theories make quantitatively different claims about the orbits of planets around the sun. ${ }^{22}$ Feyerabend acknowledged Popper as the source of this argument, and as the source of these examples as the 'starting point' of his investigations in the original 1962 version of his paper. ${ }^{23}$

Popper had acknowledged Duhem as the source of this point and the example of the relation between Kepler's laws and Newton's theory (1972 [1957], p. 200 n. 10). ${ }^{24}$ However, the point and the example are even older than that. They had been used against Hegel's claim that ' $\mathrm{t}$ ] he Newtonian formula may be derived from the Keplerian law' ([1989 [1827], p. 250, Part C, § 269) by Whewell in $1860 .{ }^{25}$ Feyerabend (1962), following Popper (1957), following Duhem (1906), had repeated Whewell's point. Thus, Feyerabend's innovation concerning the first reason for the failure of formal accounts was merely to apply Whewell's point to Nagel instead of to Hegel.

In his 1962 paper, Feyerabend distinguished such quantitative disagreements between some pairs of successive scientific theories from the second reason for the failure of formal accounts, as illustrated with other pairs of successive scientific theories, which he called 'qualitative disagreements' (discussed in Sections 5-7 of Feyerabend, 1962). The second qualitative reason for the failure of formal accounts is the existence of incommensurable concepts.

Feyerabend used the notion of incommensurability to characterize the relation between two successive fundamental scientific theories. By fundamental scientific

\footnotetext{
$\overline{22}$ In 1954, Feyerabend had used exactly this example to make the same point (1954, pp. 470-471), but apparently he was drawing on Popper's lectures.

${ }^{23}$ Matteo Collodel has brought to my attention that Watkins's memories tend to confirm that Feyerabend had this Duhemian argument from Popper. Watkins claims that Feyerabend told him that Popper's Duhemian argument had impressed him strongly when he first heard it in Alpbach in 1948 (Watkins, 2000, p. 49). When Popper reprinted his (1957) in his (1972), he added a 'Bibliographic note', emphasising three things: first, that this was his, not Feyerabend's point; second, that he had been making this argument since the 1940s; and third, that these facts had apparently been 'overlooked' by various authors (Popper, 1972, p. 205). Popper clearly felt that he was not receiving his due credit because his idea had been hijacked by Feyerabend. Feyerabend's response to this bibliographic note was to add a footnote (dated 1980) to the reprint of his (1962) in the first volume of his collected papers (1981). In it, Feyerabend chastised Popper for claiming, in the bibliographic note, the point as his own, given that it was Duhem's (apparently not realizing, as we shall see, that it is even older), and he re-emphasized that this point was only 'the starting point' of his investigation. Feyerabend also emphasized that his contribution to the subject was the second qualitative reason for the failure of formal accounts (i.e. incommensurability). See Feyerabend (1981), p. 47 n. 6, p. 91 n. 95, and (1962), p. 92 n. 112. Many of the copious acknowledgements to Popper from the original (1962) no longer appear in the 1981 reprint.

${ }^{24}$ See Duhem (1954 [1906]), pp. 190-195.

${ }^{25}$ See Whewell (1860), Appendix H. To my knowledge, it is unclear whether Duhem, Popper, or Feyerabend were aware of Whewell's argument.
} 
theories, Feyerabend meant those that have ontological implications; that is those that have implications about the very nature of reality. By calling two such theories incommensurable, Feyerabend meant that they were conceptually incompatible: the main concepts of one could 'neither be defined on the basis of the primitive descriptive terms of the other, nor related to them via a correct empirical statement' (1962, pp. 74, 90). As a consequence, it is impossible to reduce incommensurable theories formally.

In 1962, Feyerabend illustrated incommensurability with a comparison of six pairs of central concepts drawn from three episodes of fundamental theory change in the course of scientific advance: (1) the dynamical characterization of impetus in impetus theory of motion and the concept of force in the conceptual apparatus of Newtonian mechanics, ( $2 \& 3)$ the concepts of temperature and entropy in the transition from phenomenological thermodynamics to kinetic theory, and $(4,5, \& 6)$ the concepts mass, length and time in the transition from Newtonian to relativistic mechanics. $^{26}$

Feyerabend also claimed that incommensurability occurs in discussions of some age-old philosophical problems; specifically, the mind-body problem, the problem of the existence of the external world, and the problem of other minds (pp. 31, 90). Feyerabend argued that such age-old philosophical problems have not been solved because the disputants resist the kind of meaning change necessary for their dissolution.

All of these sets of concepts are incommensurable because they belong to mutually exclusive theoretical perspectives. These perspectives are mutually exclusive because they give incompatible accounts of the nature of reality. Because the meanings of their terms are provided by the theories to which they belong, ${ }^{27}$ when there is theoretical change, there are meaning changes (Feyerabend, 1962, pp. 68, 94). These changes in meaning not only affect our theoretical and observational terms. They even affect our ontology (i.e. our conception of the nature of reality). When this occurs, there is incommensurability; or as Feyerabend later put it, a 'theory is incommensurable with another if its ontological consequences are incompatible with the ontological consequences of the latter' (Feyerabend, 1981, p. xi).

Thus, Feyerabend's notion of incommensurability is intended to capture the idea of conceptual incompatibility due to changes of meaning that occur in theoretical transitions that affect our ontological beliefs. Two fundamental theories are incommensurable because the meanings of their terms are determined by the theoretical principles that govern their correct use, and these principles are qualitatively incompatible (1962, p. 58).

Let us consider the function of Feyerabend's notion of incommensurability in Feyerabend (1962). Feyerabend used the notion to attempt to expose a dogmatic element that contemporary empiricists share with school philosophies such as Platonism and Cartesianism (from whom they had tried to distance themselves by

\footnotetext{
${ }^{26}$ In subsequent publications, Feyerabend added the example of geometrical optics and wave optics, see Feyerabend (1965b), p. 227 n. 19.

${ }^{27}$ Feyerabend can, and did, simply assume this semantic principle as part of his immanent criticism of Nagel's views, as the target of his critique (Nagel's Chapter 11) also accepts it. See Nagel (1966 [1961]), pp. $352,357$.
} 
insisting on an empirical foundation for scientific knowledge). ${ }^{28}$ The dogmatic element is due to the assumption that the meanings of empirical terms remain stable through theoretical transitions; or what Feyerabend called 'the principle of meaning invariance' (ibid., p. 30). Feyerabend argued that this principle is inconsistent with the existence of incommensurable concepts.

Feyerabend drew two main consequences from the insight that some pairs of successive scientific theories are incommensurable. First, successive scientific theories that are incommensurable have no logical relations:

The order introduced into our experiences by Newton's theory is retained and improved by relativity. This means that the concepts of relativity theory are sufficiently rich to allow us to state all the facts which were stated before with the help of Newtonian physics. Yet these two sets of categories are completely different and bear no logical relation to each other. (Ibid., pp. 88-89)

Under the assumption that formal logical relations can only hold between theories if their shared terms share meanings, as they have different meanings, they cannot be brought directly into formal relations. ${ }^{29}$ This is the basis of Feyerabend's argument against formal accounts of reduction and explanation. Second, a revision in the logical empiricist conception of scientific advance is required. Older theories, and the concepts used to state them, are not corrected and absorbed, and thereby legitimised. Rather, they are rejected and replaced, having been falsified. In this way, the logical empiricists' conceptually conservative (or retentive) accounts of reduction and explanation are undermined by the existence of the development of incommensurable concepts in the course of scientific advance.

In 1965, Feyerabend further attempted to clarify his notion of incommensurability by claiming that two theories are incommensurable when the meanings of their main descriptive terms depend on mutually inconsistent principles. ${ }^{30}$ Still later, he claimed that " $[w]$ hen using the term "incommensurability" [he] always meant deductive disjointedness, and nothing else' (Feyerabend, 1977, p. 365).

In the mid-1970s, Feyerabend developed a different conception of incommensurability, which he applied to the transition from the Greek archaic, aggregate worldview of Homer to the substance worldview of Aristotle. Neto (1991) claims that Feyerabend was lead to incommensurability through his study of Greek philosophy and its relationship to Western Rationalism. This puts the cart before the horse. While this affected Feyerabend's development of the notion of incommensurability in the 1970s, originally incommensurability was not a consequence of such a comparison. ${ }^{31}$

\footnotetext{
${ }^{28}$ For a discussion, see Hoyningen-Huene (2000b).

29 See similarly Feyerabend (1958b), p. 83 and (1961c), p. 388.

${ }^{30}$ Feyerabend (1965b), p. 227. See also (1975), pp. 269-270, 276. For a discussion, see Hoyningen-Huene (forthcoming), p. 106.

31 Unfortunately, space limitations prohibit an analysis of the differences between Feyerabend's early and later notions of incommensurability. Any such analysis should consult Feyerabend's companion to Against method: the unpublished German monograph, An introduction to the philosophy of nature (my translation). It was written from the perspective of epistemological anarchism in 1971, and revised in 1976. It will soon appear as Feyerabend (forthcoming).
} 
As we shall see, Feyerabend's development of the notion of incommensurability before 1962 was heavily influenced by a number of individuals who were discussing a wide range of different topics. ${ }^{32}$ But before proceeding to investigate the historical development of his notion of incommensurability, let us consider how the term 'incommensurable' entered Feyerabend's philosophy of science in 1962. This is instructive because it highlights a major influence on Feyerabend's development of the notion of incommensurability: Gestalt psychology.

As we have seen, Fleck and Polanyi had used the term 'incommensurable' prior to 1962, and they very likely influenced Kuhn. However, there is no evidence that Feyerabend had read either Fleck or Polanyi before 1962. There is, however, another source of the notion of incommensurability that is common to both Kuhn and Feyerabend. In 1920, Köhler had written a book on the relationship between the 'mental' concepts of psychology and the 'material' concepts of physics (Köhler, 1920). A condensed version appeared in English in 1938. In the opening sentences, Köhler wrote:

In order to orient itself in the company of natural sciences, psychology must discover connections wherever it can between its own phenomena and those of other disciplines. If this search fails, then psychology must recognize that its categories and those of natural science are incommensurable. ${ }^{33}$

Köhler proceeded to suggest that while Gestalten are common in psychology, their existence in physics would 'violate the fundamentals of exact science', and he emphasized that the 'thought and language of physics were established in accordance with other points of view than [psychology, specifically psychological Gestalten]' (ibid.). Köhler's strategy for attempting to overcome this problem with the relation of psychological 'wholes' to the reductionist concepts of physics was to attempt to find such 'organic units' in physics. This is the central topic of his essay. But what connections are there between Köhler's ideas and Feyerabend's 1962 notion of incommensurability?

First of all, one of the central topics of Feyerabend's early philosophical work was Wittgenstein's Investigations. This book discusses Gestalt figures at some length (see Wittgenstein, 1958, XI, $193^{\mathrm{e}} \mathrm{ff}$.). In fact, Wittgenstein's later philosophy was heavily influenced by Gestalt psychology, especially by Köhler, ${ }^{34}$ who is one of the very few named sources in the entire book. ${ }^{35}$

\footnotetext{
${ }^{32}$ Feyerabend explicitly discussed his development of the notion of incommensurability in Feyerabend (1995), p. 92; (1978), pp. 67, 114-115; (1970b); (1987), p. 156; (1993), pp. $210 \mathrm{ff}$.

${ }^{33}$ See Köhler (1938 [1920]), p. 17; italics inserted. The term 'inkommensurabel' does not appear in the original 1920 German version. Thus, Feyerabend's use of the term 'incommensurable' appears to be the result of W. Ellis's translation.

${ }^{34}$ See Wittgenstein on the difference between 'seeing' and 'seeing as', as well as the general problems with perceptual psychology that led to the development of Gestalt psychology: Wittgenstein (1958), XI, 193 $214^{\mathrm{e}}$ and Köhler (1947), pp. 81-122.

${ }^{35}$ See Wittgenstein (1958), XI, $203^{\mathrm{e}}$.
} 
Second, Kuhn had originally used the notion of a Gestalt switch to illustrate his notion of scientific revolutions and the incommensurability involved. ${ }^{36}$ In his 1961 comments on a draft of (Kuhn, 1970a [1962]), Feyerabend had even recommended that Kuhn 'must read' Wittgenstein on the distinction between 'seeing' and 'seeing as', that is, exactly those passages of Wittgenstein's views on perceptions in which Wittgenstein cites Köhler (Feyerabend, 1995 [1960/1961], p. 384). This, by itself, is a possible indication that Feyerabend may have had the term 'incommensurable' from Köhler.

Third, Köhler was not only a founding father of Gestalt psychology, he was also active in philosophy, especially the philosophy of mind. ${ }^{37}$ Like Feyerabend, he was very interested in the consequences that the psychology of perception have for philosophical accounts of science, ${ }^{38}$ as well as the relationship between folk psychological concepts and physical concepts. This is the topic of Feyerabend (1963b,c), where Feyerabend argued against the need to reduce the former to the latter in favor of eliminative materialism. According to Feyerabend, the meanings of the 'mental' psychological terms should be eliminated, and replaced by 'materialist' physical concepts. In arguing this point, Feyerabend went so far as to claim that 'every interesting discussion, that is every discussion which leads to an advance of knowledge, terminates in a situation in which some decisive change of meaning has occurred' (Feyerabend, 1963b, p. 58). Moreover, Feyerabend used the example of the mind-body problem to illustrate his notion of incommensurable concepts in Feyerabend (1962), where he first used the term 'incommensurable'. Thus, Köhler had applied the term 'incommensurable' to an example quite similar to one Feyerabend used to illustrate incommensurability in 1962, and many times thereafter. He applied it to the difficulties in relating the holistic 'mental' concepts of psychology and the reductionist 'material' concepts of physics.

Fourth, as we have seen, Feyerabend first used the term 'incommensurable' to attack Nagel's views on the formal conditions of reduction. They appear in Chapter 11, 'The reduction of theories', of Nagel (1966 [1961]). In the same chapter, Nagel also considered the issue of 'individual wholes' or 'organic unities' (such units are supposedly more than just aggregates of independent parts or members), noting that it has been claimed that such 'wholes' exist in physics, biology, and psychology, as well as the social sciences). ${ }^{39}$ In fact, Nagel's discussion of the issue takes up some seventeen pages of the chapter. ${ }^{40}$ Who did Nagel cite on this

\footnotetext{
$\overline{36}$ See e.g. Kuhn (1970a [1962]), p. 204.

37 There is even a contribution by Köhler in the first book of which Feyerabend was an editor. See Feyerabend \& Maxwell (1966).

${ }^{38}$ By the mid-1960s at the very latest, Feyerabend was clearly aware of the basic principles of Gestalt psychology (see e.g. Feyerabend, 1965b, p. 220 n. 8 where he sets them out). But as early as his 1951 doctoral thesis, he was citing works on the psychology of perception, and his close scrutiny of Wittgenstein's Investigations in 1952, all suggest that Feyerabend was familiar with, and excited by, the implications that Gestalt psychology could have for philosophical accounts of the nature of scientific knowledge and its advance.

39 See Nagel (1966 [1961]), pp. 380 ff.

40 See ibid., pp. 380-397.
} 
issue? Nagel cited Köhler. What did Nagel cite from Köhler? Nagel cited Köhler (1938 [1920]), ${ }^{41}$ exactly where Köhler used the term 'incommensurable' to describe the relationship between some concepts in psychology and in physics - an example very similar to one of Feyerabend's oft repeated examples of incommensurability. It seems very unlikely that this is a mere coincidence. It seems more likely that when Feyerabend was preparing his criticism of Nagel's account of reduction, he had a look at the main sources Nagel cited on the difficulties with reduction, and there he found the term 'incommensurable'. Alternatively, Feyerabend (1962) may have adopted the term 'incommensurable' from Nagel himself, who had already used the phrase 'incommesurably different' in the context of discussing reduction (Nagel, 1960 [1949], p. 309).

It is likely that the term 'incommensurable' found its way into Feyerabend's philosophy of science via the influence of holistic ideas in Gestalt psychology and the potential problems they could cause for formal accounts of reduction. In this sense, the term appears in a 1938 publication by Wolfgang Köhler, and later in Nagel's (1960 [1949]) discussion of the same topic, and there are some very strong reasons that suggest that Feyerabend had it from these sources.

\section{Incommensurability as thesis I: theory change causes meaning change (1958)}

Feyerabend sometimes traced the origins of his notion of incommensurability back to his thesis $I$ in 'An attempt at a realistic interpretation of experience' (Feyerabend, 1958a). ${ }^{42}$ In that paper, Feyerabend criticized two conceptions of meaning. $\mathrm{He}$ argued against the logical positivist idea that the meaning of an observational term is determined by immediate experiences, as well as against the idea (often attributed to Wittgenstein) that meaning is determined by use. Instead, Feyerabend argued for the idea that meaning of a term, even an observational term, is determined by its theoretical context. More precisely, the meanings of observational terms are determined by the theoretical principles that govern their correct use according to our best theories. Such a contextual theory of meaning clearly differs from the idea (often attributed to Wittgenstein) that a term's meaning is, or is determined by, its use. The difference is that whereas the latter allows that common usage contributes to the meaning of a term, the former insists that common usage does not. Feyerabend even goes further in suggesting that common usage should be replaced by correct usage as determined by our best theories. This can easily be seen in Feyerabend's discussion of the meaning of the term 'temperature', where he argues that the meaning of the term is not determined by the layman's normal use, but instead by the principles of statistical thermodynamics. ${ }^{43}$

After criticising phenomenal and use theories of meanings, Feyerabend then developed Thesis I: the interpretation of an observation language is determined by

\footnotetext{
41 See ibid., pp. 392 nn. 22, 24 and p. 393 n. 26.

42 See Feyerabend (1978), pp. 67-78 and (1977), pp. $363 \mathrm{ff}$.

43 See e.g. Feyerabend (1962), pp. 76-79. See similarly Feyerabend (1958a, 1965a).
} 
the theories which we use to explain what we observe, and it changes as soon as those theories change (Feyerabend, 1958a, p. 163). Thesis $I$ is based on a contextual theory of meaning according to which the meaning of a term is determined by the theories whose truth is presupposed when it is used to describe some feature of the world. In his (1958a), Feyerabend argued that when older theories are replaced, the meanings of the observational terms used to test the theories change. Just as in Feyerabend (1962), the result is incommensurability: the idea that successive scientific theories are conceptually incompatible. Thus, thesis $I$ is unmistakably an early version of the incommensurability thesis.

With the notion of incommensurability, in his (1958a), Feyerabend challenged an implicit conceptual conservativism in logical positivism: The assumptions that theoretical terms derive their meaning solely through their connection with experience, ${ }^{44}$ and that experience itself is a stable (or unchanging) foundation on which theoretical meaning can be based. Instead of such a bottom-up version of the relation of experience and theoretical knowledge, according to which experience determines the meanings of our theories, Feyerabend argued for a top-down version, according to which our theories determine the meaning we attach to our experiences. According to Feyerabend, experience cannot be taken for granted. It takes on its particular character in light of the theories we bring to it.

Clearly, then, Feyerabend had developed a notion of incommensurability by 1958, (before he had met Kuhn in Berkeley in 1960). However, the notion of incommensurability can be found in Feyerabend's work even earlier than that, and this should come as no surprise as Feyerabend (1958) is a condensed version of Feyerabend's unpublished doctoral thesis (1951).

\section{Incommensurability and quantum mechanics: Feyerabend's attack on the conceptual conservativism implicit in Bohr's principle of complementarity (1958)}

In his autobiography, Feyerabend acknowledged Niels Bohr's influence on the development of his notion of incommensurability in the 1950s. Feyerabend recalled a conversation in which Bohr had talked about the discovery that the square root of two cannot be an integer or a fraction. According to Feyerabend, Bohr presented the event as having led to the extension of a concept of number that retained some properties of integers and fractions, but changed others; and claimed that the transition from classical to quantum mechanics was carried out in accordance with precisely

\footnotetext{
44 According to logical empiricists, the meaning of a term is grounded on experience, either directly in the case of observation terms, or indirectly in the case of theoretical terms. For example, the meaning of 'red' is determined by observations of the color red, while the meaning of a theoretical term such as 'mass' is determined by its connection to other terms such as 'weight', whose meaning is determined directly by observations. Feyerabend repeatedly challenged the epistemological and semantic significance of the distinction between observational and theoretical terms. See e.g. Feyerabend (1954), p. 470; (1958a), pp. 164-165; (1958b); (1960a,c); (1961a), p. 82; (1961b), p. 443; (1962), pp. 160-163; (1965b), pp. 198, 219-224; (1969a).
} 
this principle (Feyerabend, 1995, p. 78). As Feyerabend used his notion of incommensurability to try to capture the idea of conceptual changes that retain some properties of a concept, while changing others, these autobiographical recollections are evidence of Bohr's direct influence on Feyerabend's development of the notion of incommensurable concepts in the 1950s.

More importantly, Feyerabend used the notion of incommensurability in a publication on Bohr's complementarity thesis prior to 1962. In Feyerabend (1958b), Feyerabend argued that Bohr's complementarity thesis is an example of an unjustified conceptual conservativism in the sciences, taking issue with Bohr's contention that the account of all quantum mechanical evidence will always necessarily be expressed in classical terms. ${ }^{45} \mathrm{He}$ presented Bohr's defence of the principle of complementarity as based on the correspondence principle: the conviction that every experience must necessarily make its appearance within the frame of our customary points of view, which is currently that of classical physics. However, according to Feyerabend, just because classical concepts have been successful in the past, and because at the moment it may be difficult, or even impossible, for us to imagine how to replace them, it does not follow that the classical framework could not one day be superseded. Consequently, it does not follow that all our future microscopic theories will have to use the notion of complementarity as a fundamental notion.

Instead, according to Feyerabend, a theory may be found whose conceptual apparatus, when applied to the domain of validity of classical physics, would be just as comprehensive and useful as the classical apparatus, without coinciding with it. He claimed that such a situation is by no means uncommon, and he used the transition from Newtonian to Einsteinian physics to bolster his point. According to Feyerabend, while the concepts of relativity theory are sufficiently rich to state all of the facts captured by Newtonian physics, the two sets of categories are 'completely different' and bear 'no logical relations' to each other. ${ }^{46}$ This is clearly a version of the incommensurability thesis. On Feyerabend's fallibilist view of empirical knowledge, no element of our knowledge can be held to be necessary or absolutely certain. In our search for satisfactory explanations, we are at liberty to change any parts of our existing knowledge, however 'fundamental' they may seem, including the concepts of classical physics (Feyerabend, 1961c, pp. 323-324, 326). Thus, Feyerabend's 1958 argument against Bohr's contention of the necessity of maintaining classical concepts for the description of quantum phenomena was based on the idea that new incommensurable concepts could be invented, and one day could even be used to replace classical descriptions. ${ }^{47}$

\footnotetext{
45 Feyerabend presented a synopsis of his argument in (1962), p. 43.

46 See Feyerabend (1958b), p. 83, (1961c), p. 388, and compare (1962), pp. 88-89.

47 Feyerabend made this argument repeatedly. See Feyerabend (1958b), pp. 81-83; (1958c), pp. 50, 59 n. 6; (1960b), pp. 321 ff.; (1961c), pp. 384 ff.; (1995 [1960/1961]), pp. 378 ff.; (1962), p. 88 n. 106; (1963a, 1965b, 1970c). But around 1970, Feyerabend abandoned it (see 1970a), and completely inverted his estimation of Bohr. See and compare Feyerabend (1961c), pp. 384 ff. with (1970a) and (1993), pp. 15 n. 1, 31-32.
} 
According to Preston, Feyerabend's notion of incommensurability, though not the term itself, was first published in this 1958 paper on Bohr's thesis of complementarity. ${ }^{48}$ As we have seen, one of several chief influences on Feyerabend's development of the notion of incommensurability in the 1950s was unquestionably Niels Bohr. Even so, Preston's claim is incorrect. Feyerabend had already published the idea in German in 1954.

\section{Incommensurability and ontology: Feyerabend's attack on the conceptual conservativism implicit in attempts to separate philosophical accounts of ontology from physics (1954)}

The first use of the notion of incommensurability in Feyerabend's published work appeared in the paper 'Physik und Ontologie' (1954), which discusses the nature of major theoretical advances in physics, and their semantic and ontological implications. Feyerabend argued that major theoretical advances in physics are not part of a continuous process of enriching already established ideas, and that scientific progress is not a process in which existing ideas are improved or the number of known facts is simply increased. Instead, Feyerabend argued that new theories force a revision in the ontological status of older ideas. After major theoretical transitions, older ideas can no longer be accepted as purported true descriptions of reality. This is because they are conceptually incompatible with better ideas that are supposed to describe reality. According to Feyerabend (1954), conceptual replacements that occur in theoretical advance can have ontological implications: when new fundamental theories replace older ideas, a correspondingly new conception of reality is formed. In the course of theoretical advance in physics, what we take to be real itself is not simply improved or enriched: 'It is completely reordered' (ibid., p. 470; my translation).

Feyerabend argued for this view of scientific advance on the basis of the claim that the meanings of scientific terms are determined by the theories in which they occur. Consequently, given theory change, there is meaning change (ibid., p. 467). This is the first instance of the notion of incommensurability in Feyerabend's published work. According to Feyerabend, ontology and semantics are thus normative, not descriptive: they vary historically in accordance with theoretical advance, and when new theories replace older ones, both our conception of reality and the meanings of our terms describing it change.

Feyerabend used the notion of incommensurability to criticize an implicit conceptual conservativism in attempts to separate philosophical accounts of ontology from physics. Purely analytic attempts to explicate what we take to be real presuppose a fixed conception of reality. However, if our conception of the nature of reality is contingent upon our developing theoretical ideas, then ontology cannot be studied independently of the empirical sciences.

$\overline{48 \text { Preston }}$ (1997a), pp. 102-103, cites Feyerabend (1958b, 1961c). 


\section{Incommensurability and methodology: Feyerabend's attack on the conceptual conservativism implicit in Heisenberg's principle that established results set conditions on further research (1951)}

In his unpublished doctoral thesis, Feyerabend discussed the relationship between the general theory of relativity and Newton's theory (Feyerabend, 1951, pp. $87 \mathrm{ff}$.). He claimed that Newton's theory was replaced by the general theory of relativity, and emphasized that the latter talks about completely different relationships (ibid., p. 90). Feyerabend based this claim on the idea that the meanings of the concepts of general relativity and Newton's theory are determined by the theories to which they belong, emphasizing that when the former replaced the latter, there was meaning change (ibid., p. 89). Feyerabend also claimed that these two conceptually incompatible theories may even predict the same experimental results within their shared domains. However, as the theories used to interpret the sentences expressing the experimental result are conceptually incompatible, there will be two incommensurable interpretations of it. Feyerabend made exactly these points concerning the transition from Aristotelian dynamics to Newton's theory in the course of illustrating incommensurability in 1962 (Feyerabend, 1962, p. 57). Thus, Feyerabend had clearly employed the idea of incommensurability as early as 1951.

Moreover, in his doctoral thesis, Feyerabend used this basic idea of incommensurability in much the same way in which he used it in his $(1954,1958 \mathrm{a}, \mathrm{b}, 1962)$. He used it to attack what he considered to be an unjustified conceptual conservatism. In this instance, he attacked the conceptual conservativism implicit in the methodological principle that established results must be presupposed by all further research, as set out by Heisenberg (Feyerabend, 1951, p. 190). Feyerabend's reaction to Heisenberg's conceptual conservativism was to argue that imposing conditions on further research on the basis of established results could hinder progress. It overlooks that new concepts with different meanings could replace those older ideas. This reaction mirrors exactly his reaction to the conceptual conservativism he found in attempts to separate philosophical and scientific accounts of ontology, Bohr's complementarity thesis, logical positivist theories of meaning, and formal theories of reduction and explanation. It was also based on exactly the same idea: the possibility of developing new theories whose concepts are conceptually incompatible with those of existing theories (i.e. incommensurability).

It follows that Jacobs's assertions concerning Feyerabend's unpaid debt to Polanyi as the source of his notion of incommensurability cannot be correct. ${ }^{49}$ Polanyi's

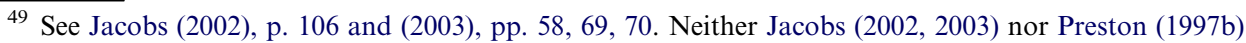
provide any instance of Feyerabend having mentioned Polanyi before the mid-1970s. They base their claims about the connection between Feyerabend and Polanyi on Feyerabend's 1991 remark that 'somewhere along the way I read an interesting paper by Michael Polanyi' (Feyerabend, 1991, pp. 492, 501; italics inserted). It is, however, clear that Feyerabend and Polanyi were acquainted at the latest by 1957. They both participated in the Ninth Symposium of the Colston Research Society held in Bristol in April of 1957, where they discussed each other's contributions. Feyerabend typed up these discussions for publication. There is even a photo of the participants in which Feyerabend is standing directly behind Polanyi. See the title page of Körner (1957).
} 
notion of incommensurability as applied to scientific theories first appeared in his (1958). ${ }^{50}$ Feyerabend had developed his notion of incommensurability by 1951, and he had already used it in publications that had appeared in 1954 and 1958. Feyerabend did not draw on Polanyi concerning his notion of incommensurability, and Polanyi had not 'presaged ... Feyerabend's motif of incommensurability' (Jacobs, 2002, p. 106). ${ }^{51}$ Feyerabend's notion of incommensurability actually pre-dates Polanyi's use of the idea as applied to scientific theories and, as we shall see, it comes from a different source.

Moreover, while there are indeed some significant similarities between Polanyi's notion of incommensurability and Feyerabend's post-1970 ideas, ${ }^{52}$ and more so between Polanyi and Kuhn's ideas, ${ }^{53}$ there are also some striking differences between Polanyi's notion of incommensurability and Feyerabend's pre-1970 ideas. For example, according to Jacobs, Polanyi used his notion of incommensurability to argue against the possibility of rationally comparing incommensurable conceptual systems (ibid., pp. 114-115). Between 1951 and 1970, Feyerabend repeatedly insisted that the existence of incommensurability does not preclude rational comparison. ${ }^{54}$

\section{Incommensurability and perception: Feyerabend's attack on the conceptual conservativism implicit in the logical positivists' foundational use of protocol sentences (1949-1952)}

Feyerabend discussed his notion of incommensurable concepts with the Kraft Circle from 1949-1951. ${ }^{55}$ The Kraft circle was a student group named after Viktor Kraft (Feyerabend's Ph.D. supervisor) and modelled after the Vienna Circle (of which Kraft was a member). Guests such as Elizabeth Anscombe and Ludwig Wittgenstein attended meetings. ${ }^{56}$

Meeting Wittgenstein and attempting to rewrite the Investigations as a treatise had a profound and long-lasting influence on Feyerabend's philosophical development. ${ }^{57}$ Feyerabend had even planned to study under Wittgenstein at Cambridge, and had received a fellowship to do so. But Wittgenstein died, so Feyerabend went to London

\footnotetext{
50 See and compare Jacobs (2002), p. 108 with pp. 111-116, and see Jacobs (2003), p. 61. Polanyi had developed a notion of incommensurability between a scientific and a religious worldview in 1946, but in his (1964 [1946]), he explicitly rejected the idea of incommensurability between scientific theories. See ibid., p. 66 and Jacobs (2003), pp. 61, 71 n. 5 for a discussion.

51 This does not rule out the possibility that Feyerabend's 1975 notion of incommensurability my have owed something to Polanyi.

52 See Preston (1997b).

53 See Jacobs (2003), p. 67 and (2002), p. 113.

${ }^{54}$ See e.g. (1965c), pp. $227 \mathrm{ff}$.

55 See Feyerabend (1978), pp. 108 ff. and (1966), pp. 3 ff.

56 See Feyerabend (1978), pp. 115-116; (1993), pp. 259-260; (1995), p. 92.

57 See Feyerabend (1995), p. 94. Anscombe had given Feyerabend an unpublished manuscript of the Philosophical investigations. Feyerabend attempted to rewrite it as an essay. See Feyerabend (1955). For details, see Oberheim (forthcoming).
} 
to work with Popper (Feyerabend, 1995, p. 86; Feyerabend, 1987, p. 312). However, Feyerabend did not develop the idea of incommensurability primarily out of Wittgenstein's Investigations. This is clear, as in developing the notion of incommensurability, Feyerabend, as we have seen, explicitly rejected the idea that the meaning of a term is, or is determined by, its use, grounding the idea of incommensurability on a contextual theory of meaning. ${ }^{58}$

Feyerabend sometimes traced the development of his notion of incommensurability back to discussions he had with Anscombe sometime between 1949 and 1952 (Feyerabend, 1978, pp. 145 ff.). ${ }^{59}$ The discussions with Anscombe concerned the nature of perception and the foundational role of observation in positivist philosophy.

According to Feyerabend's critique of logical positivism, every positivistic observation language is based upon a metaphysical (i.e. untestable) ontology (Feyerabend, 1958a, pp. 148-149). The problem lies in the tension between the positivists' maxim of testability and their foundational use of observation claims. On the one hand, knowledge claims should be verifiable. They should be subject(able) to empirical tests. On the other hand, empirical tests are supposedly made on the stable basis of intersubjectively verifiable observations. These observations are crucial to positivism because they provide the stable, empirical foundation for such tests. In other words, the reason that knowledge claims have a special epistemic status (according to logical positivism) is that they have been (or can be) tested against experience. However, in order for the observation sentences to play this foundational role for testing knowledge claims, they themselves must be stable and intersubjectively verifiable. Consequently, they cannot themselves be open to tests. Otherwise their foundational role would be undermined. Hence, a metaphysical element has seeped into science by way of the foundational role of observation sentences in testing knowledge claims. ${ }^{60}$

In this respect, logical positivism contains a dogmatic or conceptually conservative element: the foundational role of observation sentences in theory testing. Feyerabend's critique of this conservative element was based on the idea that the meanings of the terms of observation sentences are determined by the theories to which they belong. He tried to extend and enforce the maxim of testability across the whole system - not just to theoretical knowledge claims, but to the observation sentences supporting them as well. Not only should the theoretical knowledge claims be testable, but so should the observation sentences which serve as the basis for their test. In this way, Feyerabend used the notion of incommensurability to attack the foundational role of protocol sentences as an unjustifiable form of conceptual conservativism in logical positivism.

\footnotetext{
58 Moreover, Feyerabend emphasized that he first read the Investigations in detail in London in 1952, that is, after he had submitted his dissertation (Feyerabend, 1978, pp. 115-116). Elsewhere, Feyerabend also claimed to have read a manuscript of the Investigations in 1950 (Feyerabend, 1987, p. 294).

59 Feyerabend also claimed that he tried to explain this early notion of incommensurability in Popper's seminar (in 1952), and also to a small group of people at Anscombe's home in London (in 1952). See Feyerabend (1978), p. 67 nn. 114, 115; (1993), p. 260; (1995), p. 92.

${ }^{60}$ For an excellent discussion of Feyerabend's critique of foundationalism, see Couvalis (1989).
} 
As we have seen, Feyerabend used the notion of incommensurable concepts to attack several prominent forms of conceptual conservativism, such as Heisenberg's methodological principle (1951), attempts to distinguish philosophical accounts of ontology from physics (1954), the foundational role of the stability thesis in logical positivism (1951, 1958a), Bohr's principle of complementarity (1958a, 1961c, 1962, 1965b, 1970c), and the logical empiricists' models of explanation and reduction $(1962,1963 a)$. He also used the idea of incommensurability to attack forms of conceptual conservativism implicit in the monistic test models promoted by classical empiricists, the logical positivists, the logical empiricists, Popper, and Kuhn (1958a, 1962, 1963a, 1965b, 1970c); Kantian transcendental necessities (1962, 1965b,c); traditional philosophical conundrums like the problem of the existence of the external world, the problem of the existence of other minds, and especially the mind-body problem (1962, 1965b, 1967, 1969b, 1970c); certain aspects of Wittgenstein's later philosophy as well as the linguistic philosophical movement that takes the utility of everyday concepts as given and merely attempts to analyse them, without changing their meanings (or 'arguments from synonymy') (1962, 1963a, 1965b, 1969c, 1970c); Popper's conception of verisimilitude (1970b); and scientific realist characterizations of scientific knowledge and scientific advance (1970b). However, a discussion of these post-1962 uses of the notion of incommensurability to attack unjustified forms of conceptual conservativism is beyond the scope of this essay. $^{61}$

In the third English edition of Against method (but not in the two English editions that preceded it), Feyerabend emphasized that his notion of incommensurability was originally the result of considerations about the nature of perception that he had had while studying the literature on the positivists notion of 'protocol' statements (1993, p. 211). He then proceeded to give the most detailed account of his early development of his notion of incommensurability.

Following this argument I introduced the assumption that the meaning of observation statements depends on the nature of the objects described and, as this nature depends on the most advanced theories, on the content of these theories. Or as I formulated it in my first English paper on the topic [Feyerabend, 1958a]: the interpretation of an observation language is determined by the theories which we use to explain what we observe, and it changes as soon as these theories change. (Ibid., p. 211; italics inserted)

Thus, Feyerabend had discussed his notion of incommensurability with Elizabeth Anscombe by 1950 at the latest, and he used it to attack a form of conceptual conservativism inherent in the logical positivists' use of protocol statements in theory testing in 1951. Feyerabend also emphasized that it was discussions of protocol sentences, and not discussions of Wittgenstein's notion of meaning, that influenced his developing notion of incommensurable concepts (Feyerabend, 1981, pp. 49, 125).

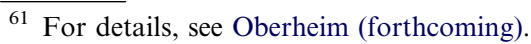




\section{Incommensurability and Pierre Duhem: the semantic implications of theoretical advance (1906)}

According to Giedymin (1982), the origins of the idea of incommensurability in the philosophy of science date back to LeRoy and Ajdukiewicz in Poincaré's conventionalist tradition. ${ }^{62}$ While something similar to the notion of incommensurability can indeed be found in Ajdukiewicz's work, there is no direct evidence connecting Ajdukiewicz to either Kuhn or Feyerabend. ${ }^{63}$

Moreover, the similarities between Ajdukiewicz's discussion of the 'untranslatability' of scientific theories is only superficially similar to Kuhn and Feyerabend's notions of incommensurability. Ajdukiewicz's concerns were with situations in which two empirically equivalent theories were nonetheless untranslatable. Here, the problem is that while they differ semantically, they do not differ empirically. For Kuhn and Feyerabend, incommensurable theories are not empirically equivalent, and Kuhn only began to use a special notion of untranslatability to help explicate incommensurability in 1969 (well after he initially introduced his notion of incommensurability). Feyerabend explicitly rejected the idea that incommensurable theories are untranslatable, insisting that one can very easily translate between two incommensurable theories (Feyerabend, 1970d, p. 233). Ajdukiewicz's discussions about the untranslatability of empirically equivalent theories appear primarily to concern the problem of the underdetermination of theory by fact, whereas Kuhn and Feyerabend's notion of incommensurability has much more to do with the theory-ladeness of observation.

However, there was another direct influence on Feyerabend's development of the notion of incommensurability that has been overlooked: The influence of Pierre Duhem. In his Ph.D. thesis, Feyerabend cited several times from The aim and structure of physical theory (Duhem, 1908 [1906]). ${ }^{64}$

Although Feyerabend cited Duhem on a different point from what he later called thesis $I$, one of the locations in which Feyerabend cited Duhem is quite revealing. Feyerabend cited Duhem directly in the middle of explaining his early conception of incommensurability - one sentence before criticizing Heisenberg's conservativism, and three sentences after writing, 'rather, the content of their statements is determined by the new law of gravitation. The concepts change their meaning corresponding to this new theory' (Feyerabend, 1951, p. 90; my translation). Thus, Feyerabend

\footnotetext{
${ }^{62}$ See Giedymin (1970), p. 257 n. 1 and (1982). See also Preston (1997a), p. 217 n. 4. The point has also been made by Wisdom (1974), p. 299, who cites Skolimowski.

${ }^{63}$ See Ajdukiewicz (1974), pp. 56-57, 67, 75-81, 86-87, (passages originally published 1934). Ajdukiewicz is indirectly connected to Kuhn, as Fleck and Ajdukiewicz appear to have been acquainted. There is a reprint of a paper by Ajdukiewicz in the University Library in Warsaw with a dedication by Ajdukiewicz to Fleck dated 1935. See Cohen \& Schnelle (1986), p. 16.

${ }^{64}$ See especially Feyerabend (1951), pp. 135 n. 75 and 142 n. 177. I will cite from the 1954 English translation, which contains all of the relevant passages to the 1908 German translation from which I will draw.
} 
cited Duhem while explaining the notion of incommensurability in 1951. But what has Duhem got to do with incommensurability?

Duhem had claimed that what a physicist states as the result of an experiment is not simply the recital of some observed facts. Rather, it is the interpretation of these facts on the basis of the theories the scientist regards as true (1954 [1906], p. 159). It follows, according to Duhem, that in order to understand the meanings that scientists ascribe to their own statements, it is necessary to understand the theories that they use in order to interpret what they observe. In other words, Duhem had stated what Feyerabend called thesis I, which, according to Feyerabend himself, is an early version of his notion of incommensurability. Moreover, exactly this passage is doubly underlined in Feyerabend's personal copy of The aim and structure of physical theory (Duhem, 1908 [1906], p. 209). ${ }^{65}$

Preston has presented Feyerabend's development of thesis $I$ as based on a misreading of Wittgenstein's theory of meaning (Preston, 1997a, pp. $23 \mathrm{ff}$.). This is incorrect. Feyerabend developed thesis $I$ from a correct reading of Duhem. As thesis $I$ is an early version of the incommensurability thesis, it follows that Feyerabend developed the notion of incommensurability from ideas he found in (Duhem, 1908 [1906]). That Duhem was indeed the uncited source of the second qualitative reason for the failure of formal accounts (i.e. incommensurability) in Feyerabend (1962) is further substantiated given that Duhem, as we have seen, was belatedly admittedly the source of Feyerabend's first quantitative reason for the failure of formal accounts of the relation between some pairs of successive scientific theories. That Duhem was also the source of Feyerabend's second reason is not surprising given that Duhem discussed the second reason (incommensurability) forty pages before he discussed the first reason (logical inconsistency) in Duhem (1954 [1906]).

After explaining that the meaning of a term depends on the theory to which it belongs, and that a consequence of theoretical advance is meaning change, Duhem continued:

If the theories admitted by this physicist are those we accept, and if we agree to follow the same rules in the interpretation of the same phenomena, we speak the same language and can understand each other. But that is not always the case. It is not so when we discuss the experiments of a physicist who does not belong to our school; and it is especially not so when we discuss the experiments of a physicist separated from us by fifty years, a century, or two centuries. (Ibid., p. 159; italics inserted)

\footnotetext{
${ }^{65}$ Feyerabend's personal copy of (Duhem 1908 [1906]) can be found in the Philosophical Archive at the University of Konstanz, Germany. It is stamped with Feyerabend's name and 1940's Vienna address, and a handwritten date suggests that he acquired it on or before 04.05 .1949 . The margins are heavily noted, and the fact that Feyerabend sometimes used his German shorthand further suggests that these notes were made in the late 1940s.
} 
To those familiar with Feyerabend and Kuhn's work, this too will sound remarkably familiar. It represents a basic point that both Feyerabend and Kuhn made with their notions of incommensurability. ${ }^{66}$ In Feyerabend's copy of Duhem (1954 [1906], p. 210), he marked this passage, and placed a small star in the margin.

Furthermore, Duhem continued:

... How many scientific discussions there are in which each of the contenders claims to have crushed his adversary under the overwhelming testimony of the facts!... How many propositions are regarded as monstrous errors in the writings of those who have preceded us! We should perhaps commemorate them as great truths if we really wished to enquire into the theories which gave their propositions their true meaning ... (Ibid., pp. 160-161; italics inserted).

Once again, this sounds extremely similar to a number of claims both Feyerabend and Kuhn made about incommensurability, and once again, this passage is underlined in Feyerabend's copy of Duhem (1954 [1906], p. 212).

The passage expresses a basic idea behind Feyerabend's notion of incommensurability, and one of its major consequences: because the older ideas are misunderstood, as a result of taking them out of the theoretical context that provides them with their correct content, disputants misunderstand each other, both claiming to have the 'facts' on their side. As is well known, both Kuhn and Feyerabend repeatedly argued this point, and claimed that in such a situation, even empirical arguments can become circular. ${ }^{67}$

Feyerabend developed thesis $I$, and consequently the incommensurability thesis, from Duhem. Duhem had already set out the ideas: (a) that the meanings of observational terms are dependent on the theories to which they belong; (b) that meaning change, even of observational terms, is a consequence of theoretical advance; and (c) that scientists have difficulties understanding members of different schools as well as those separated from them by 50,100 , or even 200 years because of meaning change

\footnotetext{
${ }^{66}$ One could argue that Duhem's ideas do not really match those of either Kuhn or Feyerabend, because Duhem suggested that the vocabulary of older theories can be translated into that of newer theories (Duhem, 1954 [1906], p. 160). However, such an argument fails to consider that Feyerabend rejected the idea that incommensurability implies untranslatability as late as 1970 (Feyerabend, 1970d, p. 233), and Kuhn only began to use a special notion of untranslatability to explicate incommensurability in 1969. For excellent discussions, see Hoyningen-Huene (1993), pp. 213 ff.; Sankey (1997, 1998). Thus, Duhem's remarks concerning translatability do not undermine the similarity to his views concerning incommensurability set out in 1962 by Kuhn and in the 1950s and 1960s by Feyerabend. Rather they bolster my point that Ajdukiewicz's problem of untranslatability is significantly different from the Duhem/Feyerabend notion of incommensurability.

${ }^{67}$ See, for example, Feyerabend (1965b), p. 152 and Kuhn (1970a [1962]), p. 94. Duhem also recognized the limitations of logic for determining the outcome of theoretical disputes in the course of scientific advance (1954 [1906], p. 218; cf. Kuhn, 1970a [1962], p. 94).
} 
due to theoretical advance. These ideas clearly anticipate the debate often co-credited to Kuhn and Feyerabend in $1962 .^{68}$

There are two main differences between Feyerabend and Duhem's notions of incommensurability. First, Feyerabend emphasized that incommensurability only occurs when fundamental theories change, as only they affect our ontology; that is, only when theoretical transitions result in a new conception of reality. ${ }^{69}$ Second, unlike Duhem, Feyerabend's conception of incommensurability is best understood in the context of his repeated attacks on various forms of conceptual conservativism.

If the notion of incommensurability in Feyerabend's early philosophy is based on the idea that scientific terms receive their meaning from the theories to which they belong, and these meanings change in the course of theoretical advance (as I have argued that it should), then the origins of Feyerabend's idea of incommensurability should be traced directly back at least to Pierre Duhem (1954 [1906]). ${ }^{70}$

\section{Conclusions}

In the first half of the last century, the idea of incommensurability was in the air. Various different versions of the basic insight that logical relations are inadequate for capturing the relations between certain pairs of successive scientific theories because meanings change in the course of theoretical advance had been proposed by Duhem, Ajdukiewicz, Fleck, and Polanyi-before the more famous introductions of the term 'incommensurable' by Kuhn and Feyerabend in 1962. All of these individuals contributed in their own ways to the development of the contemporary notions of incommensurability in the philosophy of science.

Kuhn and Feyerabend's developments of their notions of incommensurability differed significantly. Kuhn developed his notion of incommensurability out of studies in the history of science, and he was directly influenced by Fleck and Polanyi, and perhaps indirectly (through Fleck) by Ajdukiewicz. Feyerabend, on the other hand, developed his notion of incommensurability in the late 1940s and early 1950s through his studies of the bearing of the psychology of

\footnotetext{
${ }^{68}$ There are a number of other significant similarities in Duhem and Feyerabend's ideas. The most significant is the issue of realism. Both Duhem and Feyerabend understood realism as a normative ideal; that is, as the idea that our theories should be interpreted as attempts to interpret experience realistically, and not as a factual claim about the status of scientific knowledge. Moreover, both Duhem and Feyerabend used the same methodological argument in favor of such a normative realism - that by encouraging competition, it better promotes progress than instrumentalism. For details, see Oberheim (forthcoming).

${ }^{69}$ As Matteo Collodel has emphasized in remarks on a draft of this paper, it is this aspect of ontological change in Feyerabend's early incommensurability thesis (and not a contextual theory of meaning) that may be correctly attributable to Feyerabend's discussions with Anscombe.

${ }^{70}$ This also supports Giedymin's claim concerning LeRoy's contribution to the notion of incommensurability, as at the outset of the chapter in which Duhem develops the notion of incommensurability, he acknowledged LeRoy as the source of his ideas. See Duhem (1954 [1906]), p. 144 n. 1.
} 
perception on the logical positivists' foundational use of protocol statements. Köhler, and the idea from Gestalt psychology that observation is theory-laden, heavily influenced both Kuhn and Feyerabend's developments of their notions of incommensurability.

Feyerabend used his notion of incommensurability to mean that two fundamental theories are conceptually incompatible. The basic idea is that because the meanings, even of observational terms, are determined by the theories to which they belong, when there is theory change, there are meaning changes that can result in a new conception of reality. As a consequence, logical relations cannot correctly characterize the relationship between certain pairs of successive scientific theories.

Initially, Feyerabend drew his notion of incommensurability directly from Duhem. In discussions with Anscombe and Bohr in the early 1950s, he began to develop the idea as an attack on various forms of conceptual conservativism. He used the idea to attack many different forms of conceptual conservativism throughout his early philosophy. One could even say that Feyerabend's early philosophy was a series of critiques of various forms of conceptual conservativism on the basis of Duhem's insight that in the course of scientific advance, older ideas have been replaced by newer, incommensurable ones.

\section{Acknowledgements}

I would like to thank Matteo Collodel, Torbjørn Gundersen, Paul HoyningenHuene, Straun Jacobs, Ilko Kabierski, Daniel Kuby, Howard Sankey, Daniel Sirtes, Marcel Weber, and two anonymous referees for helpful suggestions on earlier drafts of this paper. I would also like to thank Brigitte Parakenings for her support from The Philosophical Archive at the University of Konstanz, Germany.

\section{References}

Agassi, E. (2002). Kuhn's way. Philosophy of the Social Sciences, 32, 394-430.

Ajdukiewicz, K. (1974). The scientific world-perspective and other essays 1931-1963 (J. Giedymin, Ed.). Dordrecht: D. Reidel.

Babich, B. (2003). From Fleck's Denkstil to Kuhn's paradigm: Conceptual schemes and incommensurability. International Studies in the Philosophy of Science, 17, 75-90.

Bird, A. (2003). Kuhn, nominalism, and empiricism. Philosophy of Science, 70, 690-719.

Carrier, M. (2001). Changing laws and shifting concepts. In P. Hoyningen-Huene, \& H. Sankey (Eds.), Incommensurability and related matters (pp. 65-90). Dordrecht: Kluwer.

Cohen, R., \& Schnelle, T. (1986). Cognition and fact. Dordrecht: D. Reidel.

Couvalis, G. (1989). Feyerabend's critique of foundationalism. Aldershot: Avebury.

Duhem, P. (1908). Ziel und Struktur der physikalischen Theorien. Leipzig: Johann Ambrosius Barth. (First published 1906)

Duhem, P. (1954). The aim and structure of physical theory. Princeton: Princeton University Press. (First published 1906)

Feyerabend, P. (1951). Zur Theorie der Basissätze. Ph.D. thesis, submitted 15 May, University of Vienna, Universitäts-Bibliothek Wien. (Obtained from the Philosophical Archive at the University of Konstanz, Germany) 
Feyerabend, P. (1954). Physik und Ontologie. Wissenschaft und Weltbild: Monatsschrift für alle Gebiete der Forschung, 7, 464-476.

Feyerabend, P. (1955). Review of Philosophical investigations. The Philosophical Review, 64, 449-483.

Feyerabend, P. (1958a). An attempt at a realistic interpretation of experience. Proceedings of the Aristotelian Society, 58, 143-170.

Feyerabend, P. (1958b). Complementarity. Proceedings of the Aristotelian Society, Suppl. Vol., 32, 75-104.

Feyerabend, P. (1958c). Reichenbach's interpretation of quantum-mechanics. Philosophical Studies, 9, 49-59.

Feyerabend, P. (1960a). On the interpretation of scientific theories. Proceedings of the 12th International Congress of Philosophy, Venice, 1958 (Vol. 5, pp. 151-159). Florence: Sansoni.

Feyerabend, P. (1960b). Professor Bohm's philosophy of nature. British Journal for the Philosophy of Science, 10, 321-338.

Feyerabend, P. (1960c). Das Problem der Existenz theoretischer Entitäten. In E. Topitsch (Ed.), Probleme der Wissenschaftstheorie. Festschrift für Viktor Kraft (pp. 35-72). Vienna: Springer.

Feyerabend, P. (1961a). Comments on Sellars's 'The language of theories'. In H. Feigl, \& G. Maxwell (Eds.), Current issues in the philosophy of science. Symposia of scientists and philosophers. Proceedings of Section L of the American Association for the Advancement of Science, 1959 (pp. 82-83). New York: Holt, Rinehart and Winston.

Feyerabend, P. (1961b). Comments on Hill's 'Quantum physics and relativity theory'. In H. Feigl, \& G. Maxwell (Eds.), Current issues in the philosophy of science. Symposia of scientists and philosophers. Proceedings of Section L of the American Association for the Advancement of Science, 1959 (pp. 441-443). New York: Holt, Rinehart and Winston.

Feyerabend, P. (1961c). Niels Bohr's Interpretation of the quantum theory. In H. Feigl, \& G. Maxwell (Eds.), Current issues in the philosophy of science. Symposia of scientists and philosophers. Proceedings of Section L of the American Association for the Advancement of Science, 1959 (pp. 371-390). New York: Holt, Rinehart and Winston.

Feyerabend, P. (1962). Explanation, reduction and empiricism. In H. Feigl, \& G. Maxwell (Eds.), Scientific explanation, space, and time (pp. 28-97). Minnesota Studies in the Philosophy of Science, III. Minneapolis: University of Minnesota Press.

Feyerabend, P. (1963a). How to be a good empiricist: A plea for tolerance in matters epistemological. In B. Baumrin (Ed.), Philosophy of science: The Delaware Seminar. New York: Interscience Press.

Feyerabend, P. (1963b). Materialism and the mind-body problem. The Review of Metaphysics, 17, 49-66.

Feyerabend, P. (1963c). Mental events and the brain. Journal of Philosophy, 60, 295-296.

Feyerabend, P. (1965a). On the 'meaning' of scientific terms. Journal of Philosophy, 62, 266-274.

Feyerabend, P. (1965b). Problems of empiricism. In R. G. Colodny (Ed.), Beyond the edge of certainty. Essays in contemporary science and philosophy (pp. 145-260). Pittsburgh: CPS.

Feyerabend, P. (1965c). Reply to criticism. Comments on Smart, Sellars and Putnam. In R. Cohen, \& M. Wartofsky (Eds.), Proceedings of the Boston Colloquium for the Philosophy of Science 1962-64: In honor of Philipp Frank (pp. 223-261). Boston Studies in the Philosophy of Science, II. New York: Humanities Press.

Feyerabend, P. (1966). Herbert Feigl: A biographical sketch. In P. Feyerabend, \& G. Maxwell (Eds.), Mind, matter, and method: Essays in philosophy and science in honor of Herbert Feigl (pp. 3-13). Minneapolis: University of Minnesota Press.

Feyerabend, P. (1967). The mind-body problem. Continuum, 5, 35-49.

Feyerabend, P. (1969a). Science without experience. Journal of Philosophy, 56, 791-794.

Feyerabend, P. (1969b). Materialism and the mind-body problem. In J. O'Connor (Ed.), Modern materialism: Readings on mind-body identity (pp. 82-98). New York: Harcourt, Brace, and World.

Feyerabend, P. (1969c). Linguistic arguments and scientific method. Telos, 2, 43-63.

Feyerabend, P. (1970a). In defense of classical physics. Studies in History and Philosophy of Science, 1, $59-85$.

Feyerabend, P. (1970b). Consolations for the specialist. In I. Lakatos, \& A. Musgrave (Eds.), Criticism and the growth of knowledge (pp. 197-230). Cambridge: Cambridge University Press. 
Feyerabend, P. (1970c). Against method: Outline of an anarchistic theory of knowledge. In M. Radner, \& S. Winokur (Eds.), Analysis of theories and methods of physics and psychology (pp. 17-130). Minnesota Studies in the Philosophy of Science, IV. Minneapolis: University of Minnesota Press.

Feyerabend, P. (1970d). Discussion at the conference on correspondence rules. In M. Radner, \& S. Winokur (Eds.), Analysis of theories and methods of physics and psychology (pp. 220-259). Minnesota Studies in the Philosophy of Science, IV. Minneapolis: University of Minnesota Press.

Feyerabend, P. (1975). Against method. Outline of an anarchistic theory of knowledge. London: New Left Books.

Feyerabend, P. (1977). Changing patterns of reconstruction. British Journal for the Philosophy of Science, $28,351-382$.

Feyerabend, P. (1978). Science in a free society. London: New Left Books.

Feyerabend, P. (1981). Realism, rationalism and scientific method. Philosophical papers. Cambridge: Cambridge University Press.

Feyerabend, P. (1987). Farewell to reason. London: Verso.

Feyerabend, P. (1988). Against method (2nd ed.). New York: Verso.

Feyerabend, P. (1991). Concluding unphilosophical conversation. In G. Munévar (Ed.), Beyond reason (pp. 487-527). Dordrecht: Kluwer.

Feyerabend, P. (1993). Against method (3rd ed.). London: Verso.

Feyerabend, P. (1995). Killing time. Chicago: University of Chicago Press.

Feyerabend, P. (1995). Two letters of Paul Feyerabend to Thomas S. Kuhn on a draft of The structure of scientific revolutions. Studies in History and Philosophy of Science, 26, 353-387.

Feyerabend, P. (forthcoming [1971/1975]). Einführung in die Naturphilosophie (An introduction to the philosophy of nature) (H. Heit, \& E. Oberheim, Eds.). Frankfurt am Main: Suhrkamp.

Feyerabend, P., \& Maxwell, G. (Eds.). (1966). Mind, matter and method: Essays in the philosophy of science in honour of Herbert Feigl. Minneapolis: University of Minnesota Press.

Fleck, L. (1979). In T. Trenn, \& R. Merton (Eds.), Genesis and development of a scientific fact. Chicago: University of Chicago Press. (First published 1935)

Fleck, L. (1980). Entstehung und Entwicklung einer wissenschaftlichen Tatsache. Frankfurt am Main: Suhrkamp. (First published 1935)

Fleck, L. (1986a). Some specific features of the medical way of thinking. In R. Cohen, \& T. Schnelle (Eds.), Cognition and fact: Materials on Ludwik Fleck (pp. 39-46). Boston: D. Reidel. (First published 1927)

Fleck, L. (1986b). Scientific observation and perception in general. In R. Cohen, \& T. Schnelle (Eds.), Cognition and fact: Materials on Ludwik Fleck (pp. 59-78). Boston: D. Reidel. (First published 1935)

Fleck, L. (1986c). The problem of epistemology. In R. Cohen, \& T. Schnelle (Eds.), Cognition and fact: Materials on Ludwik Fleck (pp. 79-112). Boston: D. Reidel. (First published 1936)

Giedymin, J. (1970). The paradox of meaning variance. British Journal for the Philosophy of Science, 21, $257-268$.

Giedymin, J. (1982). Science and convention: Essays on Henri Poincaré's philosophy of science and the conventionalist tradition. Oxford: Pergamon Press.

Hacking, I. (1983). Representing and intervening. Introductory topics in the philosophy of natural science. Cambridge: Cambridge University Press.

Hegel, G. (1989). Encyclopädie der philosophischen Wissenschaften im Grundrisse. Gesammelte Werke (19). Hamburg: Meiner. (First published 1827)

Hoyningen-Huene, P. (1993). Reconstructing scientific revolutions. The philosophy of science of Thomas $S$. Kuhn. Chicago: University of Chicago Press.

Hoyningen-Huene, P. (2000a). Paul Feyerabend and Thomas Kuhn. In J. Preston, G. Munévar, \& D. Lamb (Eds.), The worst enemy of science? Essays in memory of Paul Feyerabend (pp. 102-114). Oxford: Oxford University Press.

Hoyningen-Huene, P. (2000b). Paul K. Feyerabend: An obituary. In J. Preston, G. Munévar, \& D. Lamb (Eds.), The worst enemy of science? Essays in memory of Paul Feyerabend (pp. 3-15). Oxford: Oxford University Press.

Hoyningen-Huene, P. (2001). Paul Feyerabend und Thomas Kuhn. Journal for General Philosophy of Science, 33, 61-83. 
Hoyningen-Huene, P. (forthcoming). Three biographies: Kuhn, Feyerabend and incommensurability. In R. Harris (Ed.) Rhetoric and incommensurability. New York: SUNY.

Hoyningen-Huene, P., \& Sankey, H. (Eds.). (2001). Incommensurability and related matters. Dordrecht: Kluwer.

Jacobs, S. (2002). Polanyi's presagement of the incommensurability concept. Studies in History and Philosophy of Science, 33A, 105-120.

Jacobs, S. (2003). Two sources of Michael Polanyi's prototypal notion of incommensurability: EvansPritchard on Azande witchcraft and St Augustine on conversion. History of the Human Sciences, 16, $57-76$.

Köhler, W. (1920). Die Physischen Gestalten in Ruhe und in stationärem Zustand, Eine naturphilosophische Untersuchung. Braunschweig: Friedr. Vieweg \& Sohn.

Köhler, W. (1938). Physical Gestalten. In W. Ellis (Ed.), A source book of Gestalt psychology (pp. 17-54). London: Kegan (First published 1920).

Köhler, W. (1947). Gestalt psychology. An introduction to new concepts in modern psychology. New York: Mentor Books.

Körner, S. (Ed.). (1957). Observation and interpretation in the philosophy of physics. New York: Dover.

Kuhn, T. (1957). The Copernican revolution. Cambridge: Harvard University Press.

Kuhn, T. (1970a). The structure of scientific revolutions. Chicago: University of Chicago Press. (First published 1962)

Kuhn, T. (1970b). Reflections on my critics. In I. Lakatos, \& A. Musgrave (Eds.), Criticism and the growth of knowledge (pp. 231-278). Cambridge: Cambridge University Press.

Kuhn, T. (1977). The essential tension: Selected studies in scientific tradition and change. Chicago: University of Chicago Press.

Kuhn, T. (1979). Foreword. In L. Fleck, Genesis and development of a scientific fact (T. Trenn, \& R. Merton, Eds.) (pp. vi-xi). Chicago: University of Chicago Press.

Kuhn, T. (1981). What are scientific revolutions?. Boston: MIT.

Kuhn, T. (1983). Commensurability, comparability, communicability. In P. Asquith, \& T. Nickles (Eds.), PSA 1982. Proceedings of the 1982 Biennial Meeting of the Philosophy of Science Association (pp. 669-688). East Lansing, MI: Philosophy of Science Association.

Kuhn, T. (1989). Possible worlds in history of science. In S. Allén (Ed.), Possible worlds in humanities, arts, and sciences: Proceedings of Nobel Symposium 65 (pp. 9-32). Berlin: de Gruyter.

Kuhn, T. (1991). The road since structure. In A. Fine, M. Forbes, \& L. Wessels (Eds.), PSA 1990, proceedings of the 1990 Biennial Meeting of the Philosophy of Science Association (pp. 3-13). East Lansing, MI: Philosophy of Science Association.

Kuhn, T. (1999). Remarks on incommensurability and translation. In R. Favretti, G. Sandri, \& R. Scazzaieri (Eds.), Incommensurability and translation (pp. 33-37). Cheltenham: E. Elgar.

Kuhn (2000). The road since structure: Philosophical essays, 1970-1993, with an autobiographical interview. Chicago: University of Chicago Press.

Nagel, E. (1960). The meaning of reduction in the natural sciences. In A. Danto, \& S. Morgenbesser (Eds.), Philosophy of science (pp. 288-312). Cleveland, OH: Meridian Books. (First published 1949)

Nagel, E. (1966). The structure of science, Problems in the logic of scientific explanation. London: Kegan Paul. (First published 1961)

Neto, J. (1991). Feyerabend's skepticism. Studies in History and Philosophy of Science, 22, 543-555.

Oberheim, E. (forthcoming). Philosophical pluralism versus conceptual conservativism. Paul Feyerabend's early philosophy. (Based on On Feyerabend's early philosophy. Ph.D. thesis, University of Hannover, Germany, 2004)

Polanyi, M. (1951). The logic of liberty. Chicago: University of Chicago Press.

Polanyi, M. (1958). Personal knowledge: Towards a post-critical philosophy. London: Kegan.

Polanyi, M. (1964). Science, faith and society. Chicago: University of Chicago Press. (First published 1946)

Popper, K. (1957). The aim of science. Ratio, 1, 24-35.

Popper, K. (1972). The aim of science. In idem, Objective knowledge. An evolutionary approach (pp. 191205). Oxford: Clarendon. (First published 1957)

Preston, J. (1997a). Feyerabend. Philosophy, science and society. Oxford: Blackwell. 
Preston, J. (1997b). Feyerabend's Polanyian turns. Appraisal, 1, 30-36.

Sankey, H. (1993). Kuhn's changing concept of incommensurability. British Journal for the Philosophy of Science, 44, 759-774.

Sankey, H. (1997). Incommensurability: The current state of play. Theoria, 12, 425-445.

Sankey, H. (1998). Taxonomic incommensurability. International Studies in the Philosophy of Science, 12, $7-16$.

Sankey, H., \& Hoyningen-Huene, P. (2001). Introduction. In P. Hoyningen-Huene, \& H. Sankey (Eds.), Incommensurability and related matters (pp. vii-xxxiv). Dordrecht: Kluwer.

Watkins, J. (2000). Feyerabend among Popperians, 1948-1978. In J. Preston, G. Munévar, \& D. Lamb (Eds.), The worst enemy of Science? Essays in memory of Paul Feyerabend (pp. 47-57). New York: Oxford University Press.

Whewell, W. (1860). On the philosophy of discovery. Chapters historical and critical. London: J. W. Parker and Son.

Wisdom, J. (1974). The incommensurability thesis. Philosophical Studies, 25, 299-301.

Wittgenstein, L. (1958). Philosophical investigations. New York: Macmillan. 